\title{
Impacts of Monetary Policy and Information Shock on Stock Market: Case Study in Vietnam
}

\author{
Trung Thanh Nguyen ${ }^{1,2}$, Thi Linh Do ${ }^{3} \&$ Van Duy Nguyen ${ }^{4}$ \\ ${ }^{1}$ School of Economics, Shanghai University, Shanghai, China \\ ${ }^{2}$ Faculty of Economics and Business Administration, Hatay Community college, Hanoi, VietNam \\ ${ }^{3}$ Faculty of Accounting and Finance, Hatay Community college, Hanoi, VietNam \\ ${ }^{4}$ Viet Nam Quantitative Analysis Join Stock Company, Hanoi, Vietnam \\ Correspondence: Nguyen Trung Thanh, School of Economics, Shanghai University, 99 Shangda Road, Baoshan \\ District, Shanghai 200444, China. E-mail: ngthanhhn@ gmail.com
}

Received: March 24, 2016

Accepted: May 3, 2016

Online Published: June 25, 2016

doi:10.5539/ijef.v8n7p132

URL: http://dx.doi.org/10.5539/ijef.v8n7p132

\begin{abstract}
Evaluation of the impact of monetary policy on Vietnam stock market plays an important role for economists as well as stock investors. Stock price index not only gets impacts from the macroeconomic factors such as oil price, gold prices...but also be very sensitive to the changes in monetary policy. For each different markets, stock index are also different from each other. Hence, this artical is conducted to evaluate the impacts of monetary policy on Vietnam Stock Index (VNIDEX) in the period of the time from 2006 to 2015. The author uses GJR GARCH model and ARDL research with time-serie data by statistical methods and quantitative analysis to evaluate the above impact related to lag and shocks in the market. The result shows that the monetary policy including interests, exchange rate and required reserve ratio has a negative impact on stock price in long term. Besides, both bad or good market shock cause changes of stock price at stable level.
\end{abstract}

Keywords: ARDL model, GJR-GARCH model, monetary policy, stock price

\section{Introduction}

\subsection{Introduce the Problem}

Vietnam stock market was born in 2000 in HCM city. After that, till 2005 the Stock center in Hanoi was established. Although regarded as a newbie trading center, Vietnam Stock market has experienced the up and down periods, both strong development and severe recession. From 2005-2008 the stock price reached a top point of 1137.69 points on Mar 12th 2007, and then fell sharply to 245.74 point on Feb 24th 2009. After this period, the market grows slowly with the fluctuated level around 500 points.

At present, there are tens of billions of transaction on the Stock Exchange in Vietnam daily. Profits from stocks are the main income of many young peoples or the accumulated pension of the old (Maskay, 2007). The change (degradation) of the stock market will led to the confusion in investors' lives because it directly relates to their main income. These changes are due to the impact of international market factors (Maskay, 2007) or the monetary policy (macroeconomic) of the central bank. Therefore, the study of impacts of policies, especially monetary policy is considered as an important key which helps investors to make right decisions.

There have been many studies on fluctuation of the stock price and monetary policy. The authors approved that stock indices react sensitively to changes of monetary policy (Azali, Zare, \& Habibullah, 2013). Stock investors always follow market's changes in general and the monetary policy of the central bank in particular in order that they can make a right dicision which will bring benefit. Hence, studying impacts of factors on stock price become a vital part which helps investors to make investment decision.

Nowadays, in Vietnam, there are some studies on macroeconomics or the monetary policy (Ton \& Nguyen, 2015), however, there is no study on the long-term or short-term impacts of financial shock and the monetary on the stock price in detail. These aims of this article is following as: firstly asscessing the short term and long term impacts of the monetary policy on the stock price; and secondly considering information shock's impact on stock index. 


\subsection{Theoritical Overview}

Monetary policy is a monetary measures implemented by the Central Bank to make influence on economic activities, price stability, employment maximum and stability of the long-term interest rates (Okpara, 2010). In fact, many economists consider monetary policy as the most important macroeconomic policy (Maskay, 2007). Apart from the impact on inflation (within the allowed limit of the central bank to control inflation and supervise bank system), the monetary policy also affects other aspects of the economy such as real GDP, unemployment and exchange rates, the stock market.

The theory of "efficient market" by Fama (1970) has set an extremely important theoritical basis for policy makers as well as stock investors. Accordingly, the policy makers can freely implement the national macro-economic policies without fearing that this policy will change the essense of the stock market because they only affect the stock price index. Since then there have been many researchers focusing on the impact of these monetary policies on changes in the stock index.

Monetary policy can be conducted through many different tools such as exchange rate policy, interest rates, money supply or the required reserve. The policy of interest rates is attractive to researchers to assess the impact on the stock market. Studies have shown that interest has an opposite impact on the stock price (Ali, 2014; Dufour \& Tessier, 2006; Okpara, 2010; Fischbacher, 2012; Zare et al., 2013; Gali \& GAMBETTI, 2013). At the second rank, exchange rate policy can help investors to forrcast the market change through the exchange rate policies of central banks (Maskay, 2007; Jamil \& Ulla, 2013; Adjasi et al., 2008). Some studies also examined the impact of money supply on the stock price (Homa \& Jaffe, 1971; Hamburger \& Chochin, 1972; Maskay, 2007; Nofeldt, 2014), it showed a positive relationship between the money supply and US stock market, typically the S \& P500 Index.

Apart from three key factors, the central bank also uses some other tools in their operations as required reserve ratio for banks (Teja et al., 2013) and open market operations. However, for newbie financial markets like Vietnam, the application of the open market is not effective when the transaction is not entirely through banks. Therefore, open market operation seems not to affect to adjustment of the monetary policy as well as the stock market.

\section{Method}

\subsection{Researching Models}

In this research, the author uses the time-serie data to evaluate the immediate impacts and influctuation at lag. To solve the researh aim, the author refers the previous studies and launch research model with variables as below:

Tabel 1. Aspect and reference model

\begin{tabular}{lll}
\hline Variable name & Aspect & Authors \\
\hline Interest rate & - & Ali, 2014; Dufour \& Tessier, 2006; Okpara, 2010; Fischbacher, 2012; \\
& & Zare \& et al, 2013; Gali \& Gambetti, 2013 \\
Exchang rate & $-/+$ & Maskay, 2007; Jamil \& Ulla, 2013; Adjasi \& et al, 2008 \\
Money Supply & + & Maskay, 2007; Nofeldt, 2014 \\
Required reserve ratio & - & Teja \& et al, 2013 \\
\hline
\end{tabular}

Source: Authors' collection.

With interest rate, exchange rate, money supply and required reserve ratio are chosen as independent variables in the below model:

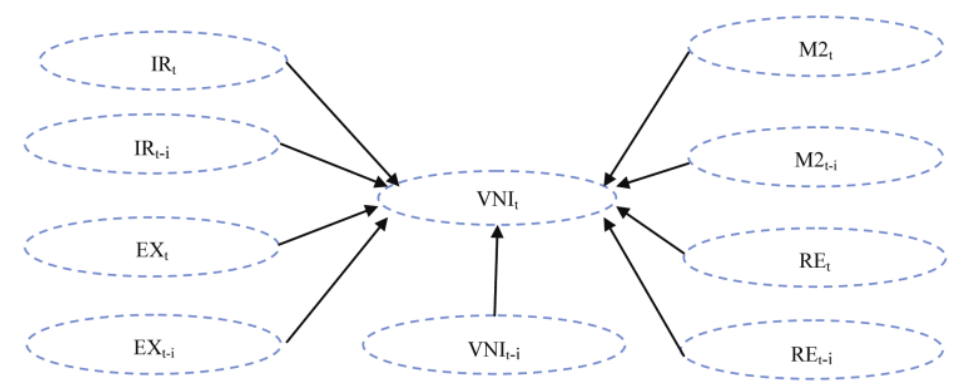

Figure 1. Researching model 
In Which:

\section{Dependent variables:}

VNI is VNINDEX price at time " $\mathrm{t}$ "

$\mathrm{VNI}_{\mathrm{t}-\mathrm{i}}$ is VNINDEX price at lag $\mathrm{i}$

\section{Independent variables:}

$\mathrm{IR}_{\mathrm{t}}$ : lending interest rates.

$\mathrm{EX}_{\mathrm{t}}$ : USD exchange rate.

M2: money supply.

$\mathrm{RE}_{\mathrm{t}}$ : required reseve ratio.

The Variables $\mathrm{IR}_{\mathrm{t}-\mathrm{i}} ; \mathrm{EX}_{\mathrm{t}-\mathrm{i}} ; \mathrm{M} 2_{\mathrm{t}-\mathrm{i}}$ and $\mathrm{RE}_{\mathrm{t}-\mathrm{i}}$ are values at lag $\mathrm{i}$.

To study the impact of these information shocks as well as monetary mutations on the stock price, the authors used the variance estimating model:

$$
h_{t}=\gamma_{0}+\delta_{1} * h_{t-1}+\ldots .+\delta_{i} * h_{t-i}+\gamma_{1} * u_{t-1}^{2}+\ldots .+\gamma_{i} * u_{t-i}^{2}+v_{1} * u_{t-1}^{2} * d_{t-1}+\ldots .+v_{i} * u_{t-i}^{2} * d_{t-i}
$$

In Which:

$\mathrm{h}_{\mathrm{t}}$ : variances

$\mathrm{d}_{\mathrm{t}}$ : variables of possitive and negative shocks.

\subsection{Method of Analysing}

To evaluate the impact of the monetary policy on the stock price, the time-serie data is used, so ARDL model is chosen to study.

For time-serie data, to ensure sustainable model before performing ARDL model, researcher used the data source (stable data chain). The stable input data will avoid fake regression case (Gurajati, 2003; Ramanathan, 2002).

Besides evaluation of the factors having impact on dependent variables, there is many invisible variables, espeically information shocks which needs being considered carefully to study changes of dependent variables in more detail. In economic models, Engle has developed the first ARCH models in 1982 and later he cooperated with Kroner to develop GARCH in 1995 to estimate further market shocks. Basing on the premise of estimating shocks by Engle, the scientists including Glosten, Jaganathan and Runkle (1993) has developed more by giving and estimating positive and negative shocks to consider any differences between them (called GJR-GARCH model).

In this study, in order to asscess impact of manetary policy on Vietnam stock market in 2006-2015, the author also uses ARDL model to evaluate the impact of market issues on stock price and GJR-GARCH to estimate positive and negative shocks in this research period.

$$
\begin{gathered}
Y_{t}=\alpha 0+\alpha 1 * Y_{t-1}+\alpha 2 * Y_{t-2}+\ldots+\alpha n * Y_{t-1}+\beta 0 * X i_{t}+\beta 1 * X i_{t-1}+\ldots+\beta n * X i_{t-n}+E_{t}+u t \\
h_{t}=\gamma_{0}+\delta_{1} * h_{t-1}+\ldots .+\delta_{i} * h_{t-i}+\gamma_{1} * u_{t-1}^{2}+\ldots .+\gamma_{i} * u_{t-i}^{2}+v_{1} * u_{t-1}^{2} * d_{t-1}+\ldots . .+v_{i} * u_{t-i}^{2} * d_{t-i}
\end{gathered}
$$

In which: $\mathrm{Y}_{\mathrm{t}}$ and $\mathrm{X}_{\mathrm{t}}$ are variables without unit root; $\mathrm{u}_{\mathrm{t}}$ is residual;

$\mathrm{Y}_{\mathrm{t}-\mathrm{n}}$ and $\mathrm{X}_{\mathrm{t}-\mathrm{n}}$ are stationary variables at lag levels.

$\mathrm{E}_{\mathrm{t}}$ is long-term impact of stationary variables of $\mathrm{X}_{\mathrm{t}}$;

$\mathrm{h}_{\mathrm{t}}$ : variances;

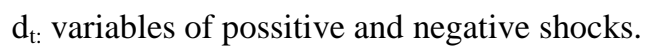

Stationary time-serie is a series with constant mean, variance, covariance at every time (Gurajati, 2003). To test stationary of time serie data, the author uses open ADF (Gurajati, 2003).

Optimal lag is lag at which variables are modeled through the lag variables and the other variables at the same lag level. The determination of the optimal lag is based on selected indicators (Hansen, 2013); these indicators are supported in EViews software.

To ensure a sustainable model, the regression equation needs to satisfy the conditions of redundant variables test (guarantee that models do not contain redundant variables - do not influence on the stock price); heteroscedasticity, autocorrelation test. 
In equation (2) if the coefficient has statistically significant, positive and negative shocks will have different impacts on the variance $h_{t}$ (Ton \& Nguyen, 2015).

\section{Results}

\subsection{Some Figures on the Monetary Policy and Stock Prices}

The input data description Statistics: In the period 2006-2015 the stock index reached 543.28 points at average; in which the maximum value reached 1137.69 points, the lowest value was 245.74 points. Credit interest rates was $12 \%$ per year at average, there was a period up to $20.25 \%$ per year in $7 / 2008$. Dollar exchange rate fluctuates around 18,789 VND/USD; consumer price index reached 107.67 at average; the money supply M2 monthly reached 2,510,000 Bil VND at average and required reserve ratio was $4.16 \%$ in the periods (Table 2).

Table 2. The period 2006-2015

\begin{tabular}{lllllll}
\hline & $\begin{array}{l}\text { VNI } \\
\text { (poit) }\end{array}$ & $\begin{array}{l}\text { IR } \\
(\%)\end{array}$ & $\begin{array}{l}\text { EX } \\
(\text { VNĐ/USD) }\end{array}$ & $\begin{array}{l}\text { CPI } \\
\text { (poit) }\end{array}$ & $\begin{array}{l}\text { M2 } \\
(\text { VND) }\end{array}$ \\
\hline Mean & 543.28 & 12.00 & 18789.41 & 107.67 & $2.51 \mathrm{E}+15$ \\
Maximum & 1137.69 & 20.25 & 21673 & 145.10 & 5.16 \\
Minimum & 245.74 & 7.23 & 15914 & 62.48 & $6.76 \mathrm{E}+14$ \\
Observations & 117 & & & & \\
\hline
\end{tabular}

Source: The authors' collection.

\subsection{Correlation Matrix}

Correlation coefficients evaluate the two-way relationship of each pair of variables. To examine the relationships as well as performance of the following analysis, the authors used the values of Loganepe which helps data series be more stable but still does not alter the transitivity characteristics between variables. Results show that the variable dependent in stock price has the strongest correlation with money supply (0.5641) and interest rate $(-0.5614)$, weakest correlation with the required reserve rate $(-0.3420)$ (Table 3$)$.

To evaluate research objectives more clearly, the authors performed a regression analysis based on GJR-GARCH and ARDL model.

Table 3. Correlation matrix

\begin{tabular}{lccccc}
\hline & LVNI & IR & LEX & LM2 & RE \\
\hline LVNI & 1 & & & & \\
IR & -0.5614 & 1 & & & \\
LEX & 0.3747 & -0.2791 & 1 & 1 & \\
LM2 & 0.5641 & -0.5631 & 0.9276 & -0.6741 & 1 \\
RE & -0.3420 & 0.4565 & -0.7015 & & \\
\hline
\end{tabular}

Source: Eviews' results.

\subsection{Unit Root Test}

To assess the impact of monetary policy on stock prices, the input variables must be ensured with data reliability in order to avoid the fake regression, data needs to be stationary (Gujarati, 2003). The test results were obtained as follows:

Table 4. Testing result for unit roots of data series

\begin{tabular}{llllll}
\hline \multirow{2}{*}{ Variables' name } & \multirow{2}{*}{ Test result ADF } & \multicolumn{4}{l}{ Statistical Value at the levels of significance. } \\
\cline { 3 - 5 } & & $1 \%$ & $5 \%$ & $10 \%$ & Prob \\
\hline LVNI & -2.387 & -3.489 & -2.887 & -2.580 & 0.148 \\
IR & -2.680 & -3.490 & -2.887 & -2.581 & 0.081 \\
LEX & -0.515 & -3.489 & -2.887 & -2.580 & 0.883 \\
LM2 & -2.373 & -3.489 & -2.887 & -2.580 & 0.152 \\
RE & -3.388 & -4.067 & -3.462 & -3.157 & 0.060 \\
\hline
\end{tabular}




\begin{tabular}{lrllll}
\hline \multicolumn{2}{l}{ THE FIRST DIFFERENCE } & & & & \\
DLVNI & -8.254 & -4.041 & -3.450 & -3.150 & 0.000 \\
DIR & -6.965 & -4.041 & -3.450 & -3.150 & 0.000 \\
DLEX & -8.565 & -4.041 & -3.450 & -3.150 & 0.000 \\
DLM2 & -9.299 & -4.041 & -3.450 & -3.150 & 0.000 \\
DRE & -4.397 & -4.070 & -3.464 & -3.158 & 0.004 \\
\hline
\end{tabular}

Source: Results from Eviwes software.

Results showed that the variables do not stop at the significant level of $1 \%, 5 \%$ and $10 \%$ so, the author uses the 1 st difference and re-tests then finds out that $1^{\text {st }}$ difference variables are satisfied for conditions of stationary. Therefore; variables are put into the regression analysis at the first difference in the following steps.

\subsection{Determining the Optimal Lag}

In the economic study with time-serie data, factors not only have an immediate impact but also influence at lag stages. To determine the optimal lag and to underestimate the influence of monetary policy on stock price correctly, authors used statistical indicators to determine appropriate lag level. Results from the data analysis in the period 2006-2015 are shown as follows (Table 5):

Table 5. The result for determining optimal lag

\begin{tabular}{lllllll}
\hline Lag & LogL & LR & FPE & AIC & SC & HQ \\
\hline 0 & 96.27573 & NA* & 0.007703 & -2.02835 & $-1.889471^{*}$ & -1.97235 \\
1 & 97.98739 & 3.195099 & $0.007583^{*}$ & $-2.044164^{*}$ & -1.87751 & $-1.976959^{*}$ \\
2 & 98.23699 & 0.460385 & 0.007711 & -2.02749 & -1.833059 & -1.94908 \\
3 & 98.58347 & 0.631352 & 0.007825 & -2.01297 & -1.790761 & -1.92336 \\
4 & 98.90625 & 0.581014 & 0.007946 & -1.99792 & -1.747936 & -1.89711 \\
5 & 99.36337 & 0.812646 & 0.008044 & -1.98585 & -1.708096 & -1.87385 \\
6 & 100.588 & 2.149956 & 0.008007 & -1.99085 & -1.685313 & -1.86764 \\
7 & 100.6321 & 0.076398 & 0.008181 & -1.9696 & -1.636294 & -1.83519 \\
8 & 100.6887 & 0.09681 & 0.008358 & -1.94864 & -1.587554 & -1.80303 \\
\hline
\end{tabular}

Source: Results from Eview software.

Results showed that the study data sources affect each other in two stages (the impact of monetary policy on stock index immediately in that month and after one month). Thus, the authors choose lag level of 1 to establish a research model.

\subsection{Testing Cointegration}

To determine the long-term relationsip between the monetary policy and the stock price, the author implemented testing for stationary variables.

Table 6. Testing cointegration

\begin{tabular}{llll}
\hline $\begin{array}{l}\text { Hypothesized } \\
\text { No. of CE(s) }\end{array}$ & Eigenvalue & Trace Statistic & Prob.** \\
\hline None $*$ & 0.560 & 149.452 & 0.000 \\
At most 1* & 0.342 & 76.300 & 0.000 \\
At most 2* & 0.283 & 39.111 & 0.003 \\
At most 3 & 0.089 & 9.558 & 0.316 \\
At most 4 & 0.014 & 1.292 & 0.256 \\
\hline
\end{tabular}

Source: Eview's result.

The results showed there are two long-term relationships between monetary policy and stock price. Therefore, by using the regressions ARDL, the author evaluates which is the long-term relationship in detail.

\subsection{Regression Results}

Since the study objective is assessing the one-way impact of monetary policy on the stock price so, the author 
focuses on regression analysis without considering the cause and effect of the relationship between variables (Granger test). Firstly the authors will give a research model of the factors that impact on the stock price, then will estimate the influence of the shock market. Final results were obtained as belows:

Table 7. Results of estimating factors' impact on stock price

\begin{tabular}{lccc}
\hline \multicolumn{1}{c}{ DLVNI } & & \\
\hline & $\boldsymbol{\beta}$ & S.E & Prob \\
C & 1.585216 & 0.8692 & 0.0682 \\
LEX(-1) & -0.14968 & 0.0864 & 0.0832 \\
IR(-1) & -0.00339 & 0.0018 & 0.0541 \\
RE(-1) & -0.01728 & 0.0041 & 0.0000 \\
\hline $\mathbf{R}^{2}$ & & $12.50 \%$ & \\
Prob(F-s) & & 0.000 & 1.977 \\
Heteroscedasticity test & & 0.6762 & 1.268 \\
Autocorrelation test & LEX(-1) & p-value $>0.1$ & 2.303 \\
\hline
\end{tabular}

Source: EVIEW system.

To make sure the reability of the estimating model, the authors tested the breach of the hypothesis of regression estimates. The results showed that the model (1) does not meet Heteroscedasticity, Autocorrelation and Multicollinearity (Table 7). It shows credibility of the conclusions from the estimating model.

Results showed that monetary policy has the opposite effect on Vietnam stock price through three policy instruments: interest rates, money supply and required reserve ratio (p-value is less than 0.05). However, the effects will have long-term impacts, but in the short-term, monetary policy seems to have no meaning in making the stock price change.

To explore the impact of information shocks, authors conducted variance estimates and obtained the following results:

Table 8. Results for market shock estimats

\begin{tabular}{lccc}
\hline & \multicolumn{3}{c}{$\mathbf{h}_{\mathbf{t}}$} \\
\cline { 2 - 4 } & $\boldsymbol{\beta}$ & $\mathbf{S . E}$ & Prob \\
\hline $\mathrm{C}$ & 0.000 & 0.000 & 0.077 \\
$u_{t-1}^{2}$ & 0.163 & 0.103 & 0.112 \\
$u_{t-1}^{2} * d_{t-1}$ & -0.231 & 0.107 & 0.031 \\
$\mathrm{~h}_{\mathrm{t}-1}$ & 0.811 & 0.106 & 0.000 \\
\hline
\end{tabular}

Source: Eview's results.

The shock is estimated by the residual value and the variance is in the previous period 1 unit. The variance $\left(\mathrm{h}_{\mathrm{t}-1}\right)$ at lag 1 has statistical significance (p-value is less than 0.05 ) indicates influence the information to the stock market. Also, the p-value of the equilibrium coefficient of positive or negative shocks $\left(u_{t-1}^{2} * d_{t-1}\right)$ by 0.03 (less than 0.05) and negative beta coefficient indicates the bad information elements will have less affect than good information (Glosten, Jaganathan, \& Runkle, 1993).

\section{Discussion}

Stock price index of Vietnam from 2006 till now has strong change periods (stock bubble), which helped pushing stock prices higher (1137 points) but then the stock price plummeted due to economic crisis in the mid of 2008. It can be said the period of 2006 to 2007 was the beginning of the Vietnam stock market as well the golden period. However, mainly because of the development by leaps and bounds in a short time, the shortage of 
preparation for the change of the market as well as the integration process, it made investors not react to the economic crisis of 2008 in time, and made market plunge to below 300 points (Figure 2).

VNI

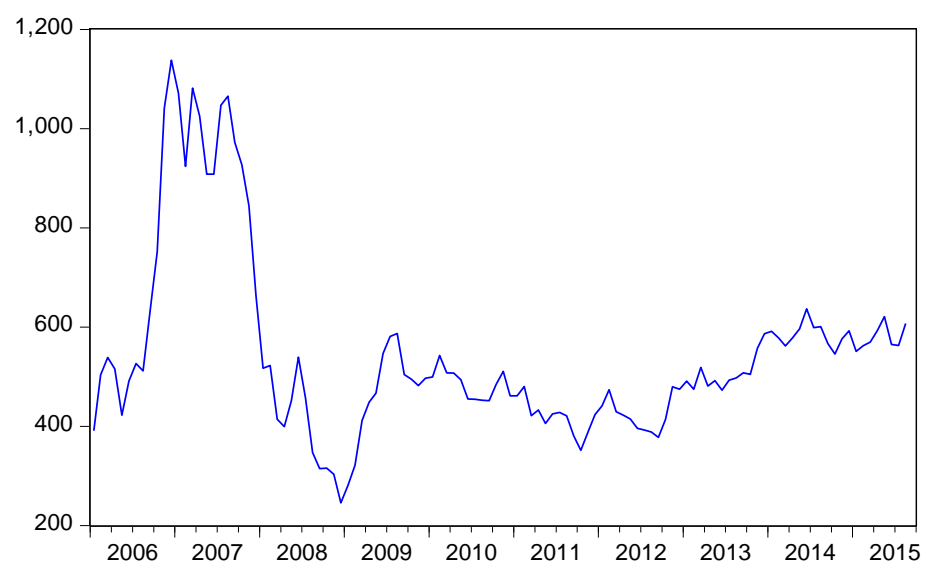

Figure 2. Stock price over the year

Research results show that the monetary policies (interest rate, exchange rate and required reserve ratio) have long-term impacts on the stock price. At the same time, the monetary policy limits stock price (oppositte impact on the stock price). The factor of Money supply seems to be no meaning in changing stock market.

Interest rates have the opposite effect on the stock price. It shows that tightening the monetary (increasing interest rates) would make the stock market decrease. In the case of high inflation, state banks have tightened the monetary policy by raising interest rates, which in the short term will not affect the stock market, but in the long term it will have negative affect to businesses, especially companies that use large amounts of bank loans for their business operations. The research results of interest rate is compatible with previous studies of (Ali, 2014; Dufour \& Tessier, 2006; Okpara, 2010; Fischbacher, 2012; Zare et al., 2013; Gali \& GAMBETTI, 2013).

The policy of required reserve ratio also has the opposite effect on the stock price. Increasing the ratio of required reserve in banks limited the amount exchanged between banks and outside individuals, business. In the short time, companies can invest or make liquidity by external borrowings. However, in the longer term, increasing required reserve ratio will causes many difficulties for enterprises' business activities.

The exchange rate VND/USD has a negative impact on the stock price. It shows that adjusting exchange rate or currency devaluating will make stock market get worse.the reason comes from an increase in import price making difficulties for enterprises. It causes business activities in the country get worse and stock price decrease.

Information Shock has affected stock market prices, the good news shock has more powerful than the bad news. This suggests that investors always appreciate good information shock. When there is good information flows from market, it will fluctuate stock price (stock price increase). But, if receiving the bad information flow, prices fluctuate with smaller amplitude.

\section{References}

Adjasi, C., Harvey, S. K., \& Agyapong. (2008). Effect of Exchange Rate Volatility on the Ghana Stock Exchange. African Journal of Accounting, Economics, Finance and Banking Research, 3(3), 28-47.

Ali, H. (2014). Impact of Interest Rate on Stock Market; Evidence from Pakistani Market. Journal of Business and Management, 16(1), 64-6.

Dufour, J. M., \& Tessier, D. (2006). Short-Run and Long-Run Causality between Monetary Policy Variables and Stock Prices. Bank of Canada Working paper.

Engle, R. F. (1982). Autoregressive Conditional Heteroscedasticity with Estimates of the Variance of United Kingdom Inflation. Econometrica, 50(4), 987-1007. http://dx.doi.org/10.2307/1912773

Engle, R. F., \& Kroner, K. F. (1995). Multivariate simultaneous GARCH. Econometric Theory, 122-150. http://dx.doi.org/10.1017/S0266466600009063 
Fama, E. F. (1970). Efficient Capital Markets: A Review of Theory and Empirical Work. The Journal of Finance, 25(2), 383-417.

Fischbacher, U., Hen, T., \& Zeisberger, S. (2012). The impact of monetary policy on stock market bubbles and trading behavior: Evidence from the lab.

Gali, J., \& Gambetti, L. (2013, 2014, 2015), The Effects of Monetary Policy on Stock Market Bubbles Some Evidence. Nber Working Paper Series.

Glosten, L. R., Jaganathan, R., \& Runkle, D. E. (1993). On the Relation between the Expected Value and the Volatility of the Nominal Excess Return on Stocks. The Journal of Finance, 48(5), 1779-1801. http://dx.doi.org/10.1111/j.1540-6261.1993.tb05128.x

Gurajati, D. N. (2003). Basic Econometrics. McGraw Hill.

Hansen, B. E. (2014). Econometrics. University of Wisconsin.

Homa, K. E., \& Jafee, D. M. (1971). The Supply of Money and Common Stock Prices. The Journal of Finance, 25(5), 1045-1066. http://dx.doi.org/10.1111/j.1540-6261.1971.tb01747.x

Jamil, M., \& Ulla, N. (2013). Impact of Foreign Exchange rate on stock prices. Journal of Business and Management, 7(3), 45-51.

Maskay, B. (2007). Analyzing the Effect of Change in Money Supply on Stock Prices. The Park Place Economist, 15, 72-97.

Menike, L. M. C. S. (2006). The Effect of Macroeconomic Variables on Stock Prices in Emerging Sri Lankan Stock Market. Sabaragamuwa University Journal, 6(1), 50-67.

Nofeldt, O. (2014). The effects of Monetary Policy on Stock Market Returns. UMEA University, pp. 1-34.

Okpara, G. C. (2010). Monetary Policy and Stock Market Returns: Evidence from Nigeria. Journal Economic, $1(1), 13-21$.

Ramanathan, R. (2002). Introductory Econometrics with Applications. Harcourt College Publishers.

Sprinkel, B. W. (1964). Money and Stock Prices. New York: Richard D. Irwin, Home wood, III.

Teja, K. R., Tejaswi, M., Madhavi., \& Ujwala, G. (2013). Cash Reserve Ratio impact on Stock Market (India) in Long run. International Journal of Marketing, Financial Services \& Management Research, 2(8), 85-93.

Ton, H. T. H., \& Nguyen, V. N. (2015). The Impact of The International Price Index on Vietnam Stock Market. International Conference on Emerging Challenges: Managing to Success, 1, 132-138.

Zare, R., Azali, M., \& Habibullah, M. S. (2013). Monetary Policy and Stock Market Volatility in the ASEAN5: Asymmetries over Bull and Bear Markets. International Conference on Economics and Business Research 2013, pp. 18-27. http://dx.doi.org/10.1016/s2212-5671(13)00213-x

\section{Copyrights}

Copyright for this article is retained by the author(s), with first publication rights granted to the journal.

This is an open-access article distributed under the terms and conditions of the Creative Commons Attribution license (http://creativecommons.org/licenses/by/3.0/). 